\title{
AUTONOMIC NEUROPATHY IN RHEUMATOID ARTHRITIS
}

\author{
BY \\ P. H. BENNETT AND J. T. SCOTT \\ From the Department of Medicine, Postgraduate Medical School, London
}

Neuropathy of the somatic nervous system in rheumatoid arthritis is well documented. Peripheral neuropathy of sensory and sensori-motor types, multiple involvement of peripheral nerves (mononeuritis multiplex), digital neuropathy and lesions due to intrinsic pressure on single nerves are all described (e.g. Hart, Golding, and Mackenzie, 1957; Pallis and Scott, 1965). There is, however, a single report suggesting that interruption of the autonomic pathways may occur. Kalliomäki, Saarimaa, and Toivanen (1963) found that females with rheumatoid arthritis failed to sweat in response to an intradermal injection of nicotine on the forearms as compared with a matched group of control subjects. This failure appeared to be correlated with the presence of cold hands and a high erythrocyte sedimentation rate. No mention was made of clinical neuropathy in this study.

The present investigation was undertaken to determine the presence, extent, and location of autonomic nerve involvement in adult subjects with various types of rheumatoid neuropathy. Control subjects and patients with uncomplicated rheumatoid arthritis were also examined.

\section{Physiology of Sweating}

Sweating is an easily demonstrable autonomic function and is mediated by sympathetic nerves. The higher centres for thermo-regulatory sweating are generally thought to be situated in the hypothalamus (Hasama, 1930). The pathway of the long tracts is uncertain, but the preganglionic fibres, whose ganglion cells lie in the lateral horns between the first thoracic and first lumbar segments, emerge in the thoraco-lumbar outflow with the nerve roots and pass to the sympathetic ganglia where they terminate in a synapse. The cell body of the postganglionic neurone usually lies in one of the ganglia of the sympathetic chain. The postganglionic nerve emerges from the ganglion as the grey ramus communicans and passes to the periphery either with a main nerve trunk or in relation to a blood vessel (Fig. 1). In the dermis the nerve supplies sweat glands, erector pilae muscles, and the smaller blood vessels. The fibres divide terminally and a single nerve fibre may supply more than one structure and also act as a receptor for certain stimuli. Sym. pathetic nerves from $\mathrm{T} 1-5$ segments supply the upper limbs and from $\mathrm{T} 5-\mathrm{L} 1$ the lower limbs (Mitchell, 1953).

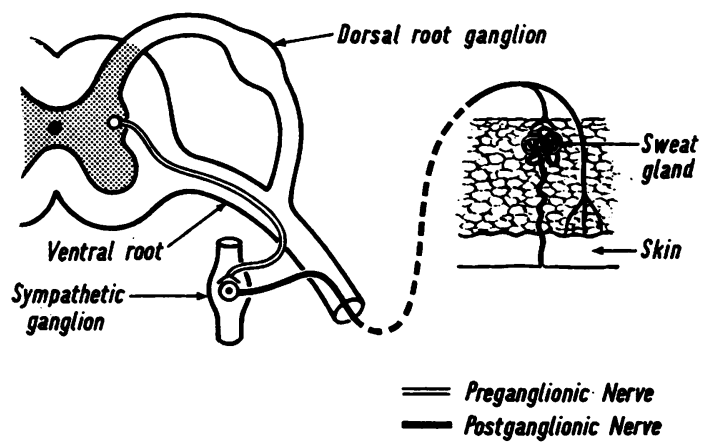

Fig.1 - Sympathetic pathway to sweat glands.

Postganglionic sympathetic fibres mediate the sympathetic axon reflex as described by Lewis and Marvin (1927). Antidromic impulses pass up the postganglionic fibre and produce a response in the effector organ. This is shown by the following experimental data:

(1) Goose skin in response to faradic skin stimulation is abolished by extirpation of the stellate ganglion in cats (Lewis and Marvin, 1927).

(2) Local sweating in response to faradic skin stimulation is abolished by a novocaine skin wheal at the site of stimulation, by injury to the brachial plexus, and by ganglionic sympathectomy, but remains intact after preganglionic sympathectomy. The response remains after 
blocking a cutaneous nerve with local anaesthetic at a point some distance proximal to its termination. Hence the response is of the axon reflex type and is mediated by postganglionic sympathetic nerves (Bickford, 1938; Wilkins, Newman, and Doupe, 1938).

(3) It has been shown in the cat that sweating and piloerection cannot be elicited by electrical stimulation of the distal portion of the severed dorsal root, hence the response is not mediated by sensory nerves. The response is, however, obtained on stimulation of the ventral roots (Collins and Weiner, 1961).

(4) It has been observed that intradermal injection of acetyl choline or nicotine results in local sweating and piloerection. This does not occur after postganglionic sympathetic nerve degeneration following ganglionectomy. It therefore appears that sweating and piloerection which follow an intradermal injection of nicotine or acetyl choline are mediated by a sympathetic axon reflex and that this response can be used to test the integrity of postganglionic sympathetic nerves in a manner analogous to that of histamine and the sensory neurone (Rothman and Coon, 1939; Coon and Rothman, 1940).

In normal subjects body heating causes symmetrical sweating on the limbs and face (List and Peet, 1938), the magnitude of the response probably being proportional to the density of sweat glands in the area. Lesions of either the pre- or postganglionic sympathetic pathways will result in deficient or absent sweating. The integrity of the postganglionic fibre can be tested by the cutaneous response to an intradermal injection of nicotine or acetyl choline, or to faradic stimulation. If the postganglionic fibre supplying an area of deficient thermo-regulatory sweating is intact, sweating and piloerection will be seen, hence the thermo-regulatory sweating abnormality must be due to involvement of the preganglionic nerve. Absent sweating and piloerection in the abnormal area signifies interruption of the postganglionic fibre, provided that the presence of functioning sweat glands can be shown. This can be demonstrated by the effect of local heating to the area (Janowitz and Grossman, 1950).

\section{Methods}

The methods used were similar to those employed by Bárány and Cooper (1956) in a study of diabetic patients. Thermo-regulatory sweating was produced by placing the subject in a bath of water at about $44^{\circ} \mathrm{C}$. after the limbs, which were supported above the water level, had been covered with 5 per cent. castor oil in iodine paint and sprayed with starch powder from an insufflator (Minor, 1927).

Subjects who were not already receiving salicylates in large doses were given soluble aspirin $900 \mathrm{mg}$. one hour before the test and all were given a hot cup of tea or coffee immediately before the limbs were prepared. The resulting sweat response appeared as blue-black dots which later coalesced.

The areas in which sweating occurred after the subject had been heated for 30 minutes were charted. The maximum area of sweating was always apparent after 20 minutes' immersion. The only side effects of this procedure were the appearance of a transient erythematous rash on the limbs of three female patients in the areas painted with iodine and a syncopal attack in one female patient after getting out of the bath. During the procedure the oral temperature rose by 1 to $3^{\circ} \mathrm{F}$. and tachycardia was frequently observed. None of the subjects had severe anaemia or congestive heart failure.

The areas of skin in which sweating was either grossly deficient or absent were then tested by faradic stimulation and by intradermal injection of acetyl choline. Faradic stimulation was provided by means of two silver electrodes $3 \mathrm{~mm}$. apart, placed on the skin after cleaning with ether. The electrodes were connected to a standard Multitone faradic stimulator, using a stimulus to pain tolerance of as short a duration and of as great a frequency as possible. In normal subjects (and in normal areas in abnormal subjects) sweating was seen after stimulation for 2 minutes. Its presence was detected by applying quinizarin powder to the skin before stimulation. Quinizarin, which turns deep purple where there is sweating, was found to be more convenient than starch and iodine for testing small areas of skin. Stimulation in all test areas was continued for 4 minutes. A few subjects failed to sweat in normal areas (i.e. where thermo-regulatory sweating had been demonstrated) probably because low pain tolerance prevented adequate stimulation.

$0.1 \mathrm{ml} .1$ per cent. acetyl choline solution in normal saline (preliminary experiments had shown this concentration to give the maximal sweat response after 45 to 60 seconds) was injected intradermally into areas of deficient sweating in all subjects. Nicotine was also used in some subjects but was found to be less effective than acetyl choline.

A sweat response to both faradism and to the intradermal injection of acetyl choline was seen in an area 5 to $7 \mathrm{~cm}$. in diameter around the point of stimulation. The intensity of the response was greatest on the dorsum of the hands, feet, and forearms, and was least on the outer aspect of the legs. It appeared to be proportional to the density of the sweat glands in the test areas. In expressing results, the term "sweat loss" means completely absent or grossly defective sweating.

In areas which showed both abnormal thermoregulatory sweating and absent sweating after faradism and acetyl choline, the presence of sweat glands was confirmed by heating the test area with a bottle containing water at $80^{\circ} \mathrm{C}$. for 2 minutes. This invariably produced local sweating in all subjects.

In order to test the validity of these methods three subjects with well documented neurological disorders were examined: 


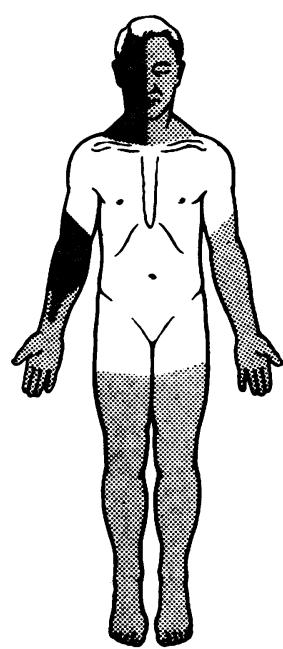

(a)

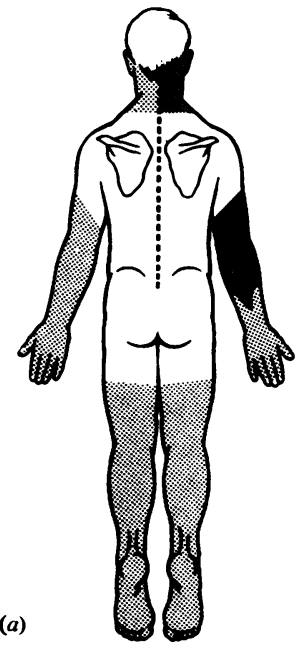

Sweating present in response to body heating.

Absent sweating in response to body heating. acetylcholine, and faradism

Fig. 2.-Sweating response.

Subject 1. Syringomyelia with classical dissociated sensory loss on the arms and a right Horner's syndrome (Fig. 2a).-Deficient sweat response occurred on the right arm and forearm and on the right side of the face. Local sweating occurred in these areas in response to faradic stimulation and intradermal acetyl choline injection. This was in accordance with the expected pattern and indicated damage to the preganglionic nerve.

Subject 2. Bilateral lumbar sympathectomy; right cervical (ganglionic) sympathectomy with surgically induced right Horner's syndrome (Fig. 2b).- - Sweating in response to faradic stimulation and intradermal acetyl choline injection did not occur in the abnormal areas, but did so in response to local heating. This indicated that the postganglionic nerve fibres were interrupted.

Subject 3. Vascular occlusion left middle finger; left cervical sympathectomy.-Thermo-regulatory sweating in this subject before sympathectomy showed a normal
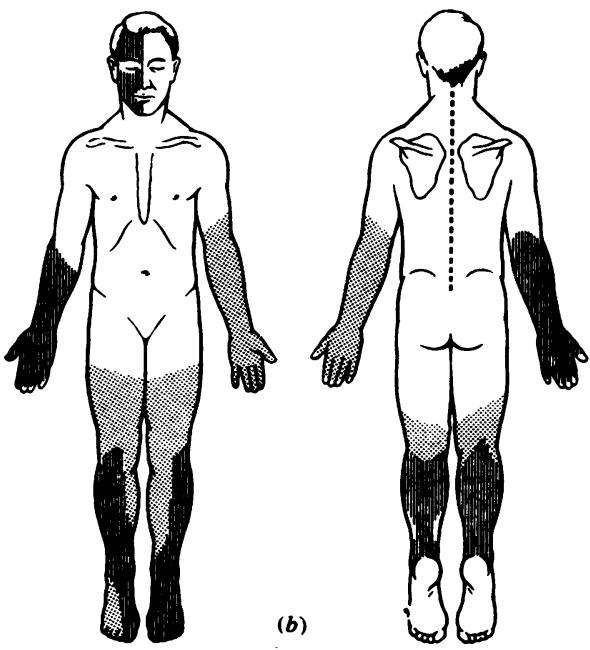

Absent sweating in response to body heating but present with acetylcholine and faradism.

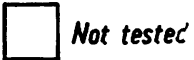

(a) Subject $1 \quad(b)$ Subject 2

pattern and local tests showed no abnormality of the postganglionic fibres. 14 days after sympathectomy, thermo-regulatory sweating was almost completely abolished in the left arm, but the local sweat responses to acetyl choline and faradism remained normal; 6 months after sympathectomy these local responses had disappeared. This indicated that degeneration of the peripheral portion of the postganglionic nerve had to occur before the response disappeared. The local heating response remained normal.

\section{Results}

The numbers and types of patients examined by these methods are shown in Table I.

\section{(1) Non-rheumatoid Controls}

Eight male and five female subjects, who were healthy or who were suffering from diseases other

TABLE I

PATIENTS EXAMINED

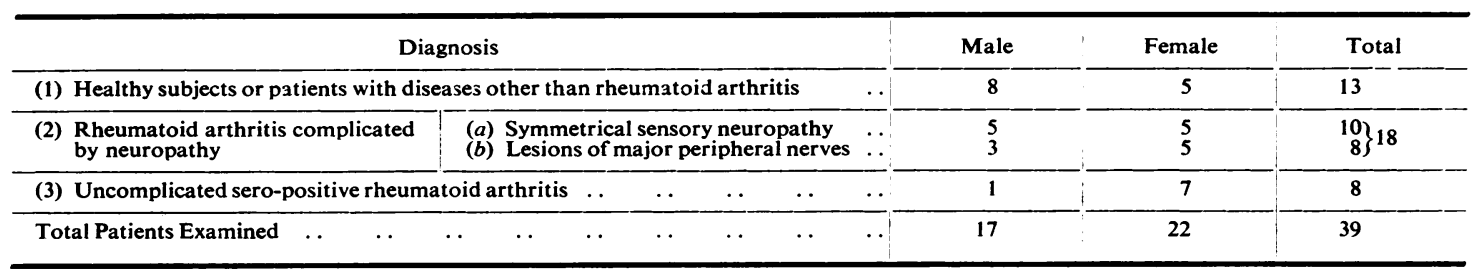


than rheumatoid arthritis, were examined. They were of similar age to the patients with rheumatoid neuropathy.

In all except one the areas of deficient thermoregulatory sweating were small and strictly symmetrical. In one subject, a female of 65 years with tophaceous gout, sweating failed to occur on the dorsum of the forearm and local tests with faradism and acetyl choline were negative. There was no sensory loss in the limbs of this patient.

\section{(2) Patients with Rheumatoid Arthritis* complicated by Neuropathy}

Two groups of patients with rheumatoid neuropathy have been examined, those with a symmetrical peripheral sensory neuropathy and those with a lesion of one or more main peripheral nerves. The

* All patients satisfied the American Rheumatism Association criteria for "definite rheumatoid arthritis" (Ropes, Bennett, Cobb, Jacox, and Jessar, 1959). types of clinical neurological deficit and sweating abnormalities are listed in Table II, and the areas of sensory and sweating loss in Cases 6, 12, and 18 are shown in Fig. 3 ( $a$ and $b$, opposite), and Fig. 3 (c, overleaf).

Of the ten subjects with symmetrical sensory neuropathy, eight had sweating abnormalities of postganglionic type. In most of them the areas of sweating loss corresponded fairly closely to those of sensory impairment. In the other two sweating loss appeared to be of preganglionic type.

Of the eight patients with lesions of main peripheral nerves, three showed postganglionic loss and in two of these the areas corresponded closely to those of sensory impairment; in three there was a normal sweating response; and in two the sweat loss was of preganglionic type.

In addition to the features listed in Table II, all but two of the eighteen patients with rheumatoid neuropathy showed absent or reduced sweating on

TABLE II

DETAILS OF NEUROPATHY IN EIGHTEEN PATIENTS

\begin{tabular}{|c|c|c|c|c|}
\hline Type of Neuropathy & Case No. & Sex & Sensory Loss & Pattern of Sweat Response \\
\hline \multirow{10}{*}{$\begin{array}{l}\text { (a) Symmetrical Sensory } \\
\text { Neuropathy }\end{array}$} & 1 & $\mathbf{M}$ & Distal leg and knees, ankles and feet & $\begin{array}{l}\text { Postganglionic: less extensive than sensory } \\
\text { loss }\end{array}$ \\
\hline & 2 & $\mathbf{M}$ & Dorsum of feet and ankles & $\begin{array}{l}\text { Postganglionic: similar area to sensory } \\
\text { loss }\end{array}$ \\
\hline & 3 & $\mathbf{M}$ & $\begin{array}{l}\text { Dorsum of feet and ankles; small area } \\
\text { dorsum right hand }\end{array}$ & $\begin{array}{l}\text { Postganglionic: similar area to sensory } \\
\text { loss }\end{array}$ \\
\hline & 4 & $\mathbf{M}$ & Feet and ankles, recovering & $\begin{array}{l}\text { Normal sweating in areas of sensory loss } \\
\text { but postganglionic loss lateral side of } \\
\text { one calf }\end{array}$ \\
\hline & 5 & $\mathbf{M}$ & Feet and ankles, recovered & Preganglionic type: lateral aspect one leg \\
\hline & 6 & $\mathbf{F}$ & Feet and hands & $\begin{array}{l}\text { Postganglionic: more extensive than sen- } \\
\text { sory loss }\end{array}$ \\
\hline & 7 & $\mathbf{F}$ & Feet, recovering & Postganglionic: forearms only \\
\hline & 8 & $\mathbf{F}$ & Feet, recovering & Preganglionic: lateral aspect one leg \\
\hline & 9 & $\mathbf{F}$ & Feet and ankles & $\begin{array}{l}\text { Postganglionic: similar area to sensory } \\
\text { loss }\end{array}$ \\
\hline & 10 & $\mathbf{F}$ & Feet and ankles & $\begin{array}{l}\text { Postganglionic: similar area to sensory } \\
\text { loss }\end{array}$ \\
\hline \multirow{8}{*}{$\begin{array}{l}\text { (b) Lesions of Main } \\
\text { Peripheral Nerves }\end{array}$} & 11 & $\mathbf{M}$ & $\begin{array}{l}\text { Bilateral terminal branches of femoral } \\
\text { nerves; median }\end{array}$ & Normal \\
\hline & 12 & $\mathbf{M}$ & Bilateral lateral popliteal, recovering & $\begin{array}{l}\text { Postganglionic: similar area to sensory } \\
\text { loss } \\
\text { Also preganglionic: one forearm }\end{array}$ \\
\hline & 13 & $\vec{M}$ & Lateral popliteal, recovered & $\begin{array}{l}\text { Preganglionic, area corresponding poorly } \\
\text { to that of sensory loss }\end{array}$ \\
\hline & 14 & $\mathbf{F}$ & Bilateral median & Normal \\
\hline & 15 & $\mathbf{F}$ & Posterior interosseus, recovered & Normal \\
\hline & 16 & $\mathbf{F}$ & Bilateral lateral popliteal, recovering & Postganglionic : similar area to sensory loss \\
\hline & 17 & $\mathbf{F}$ & Lateral popliteal, recovering & Preganglionic: similar area to sensory loss \\
\hline & 18 & $\mathbf{F}$ & Ulnar nerve, recovered & $\begin{array}{l}\text { Postganglionic; extensive areas both arms } \\
\text { and legs }\end{array}$ \\
\hline
\end{tabular}


(i) Sweating Response
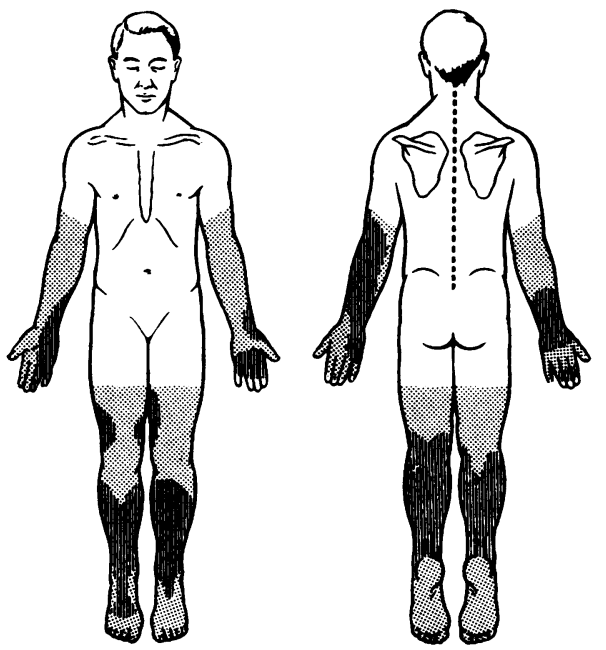

(ii) Sensory Loss
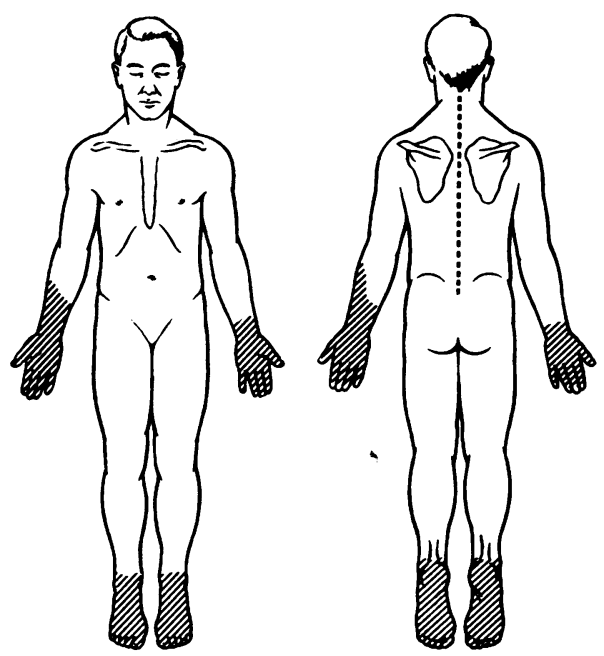

Fig. 3(a).-Case 6
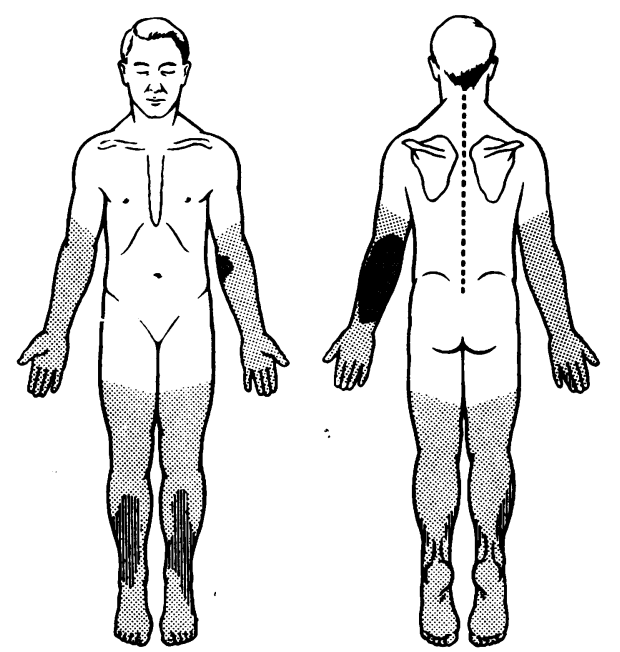

See Fig. 2 for key to sweating response
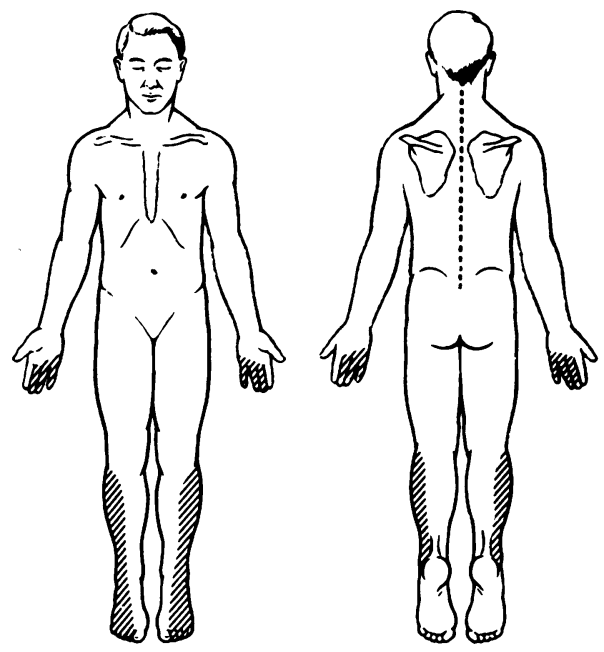

Sensory Loss

Fig. 3(b).-Case 12

one or more fingers. Ten patients had at some time or other been noted as showing signs of digital sensory neuropathy (Pallis and Scott, 1965) and in five there was some digital sensory impairment at the time of sweat testing. In four of these the areas in which sweating was deficient corresponded to those in which there was sensory loss. In two patients there were areas of analgesia and sweat deficiency (of the postganglionic type) on the dorsum of the hand and these correspond with each other extremely closely. The significance of reduced sweating in the fingers of patients with rheumatoid neuropathy is difficult to assess, because areas of impaired sweating were demonstrated in the fingers of six of the thirteen control subjects, none of whom showed any sensory loss. 
(i) Sweating Response

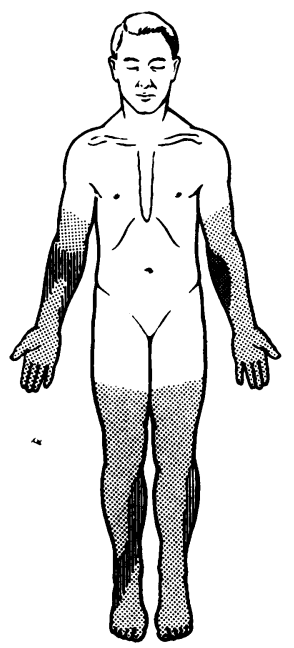

See Fig. 2 for key to sweating response (ii) Sensory Loss
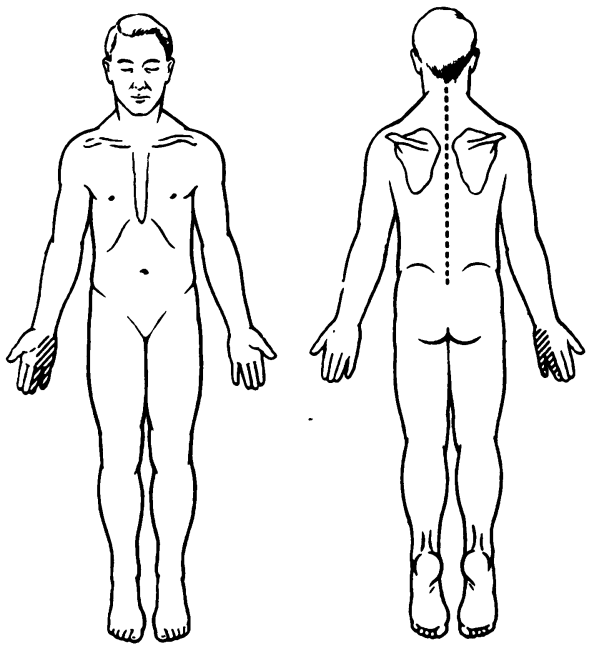

Sensory Loss

Fig. 3(c).-Case 18

(3) Patients with Uncomplicated Sero-positive Rheumatoid Arthritis

One male and seven females with rheumatoid arthritis but with no clinical evidence of neuropathy were examined. Two of these patients showed abnormalities in sweat response outside the control range: both had patchy areas of sweat loss on the arms and legs (Fig. 4).
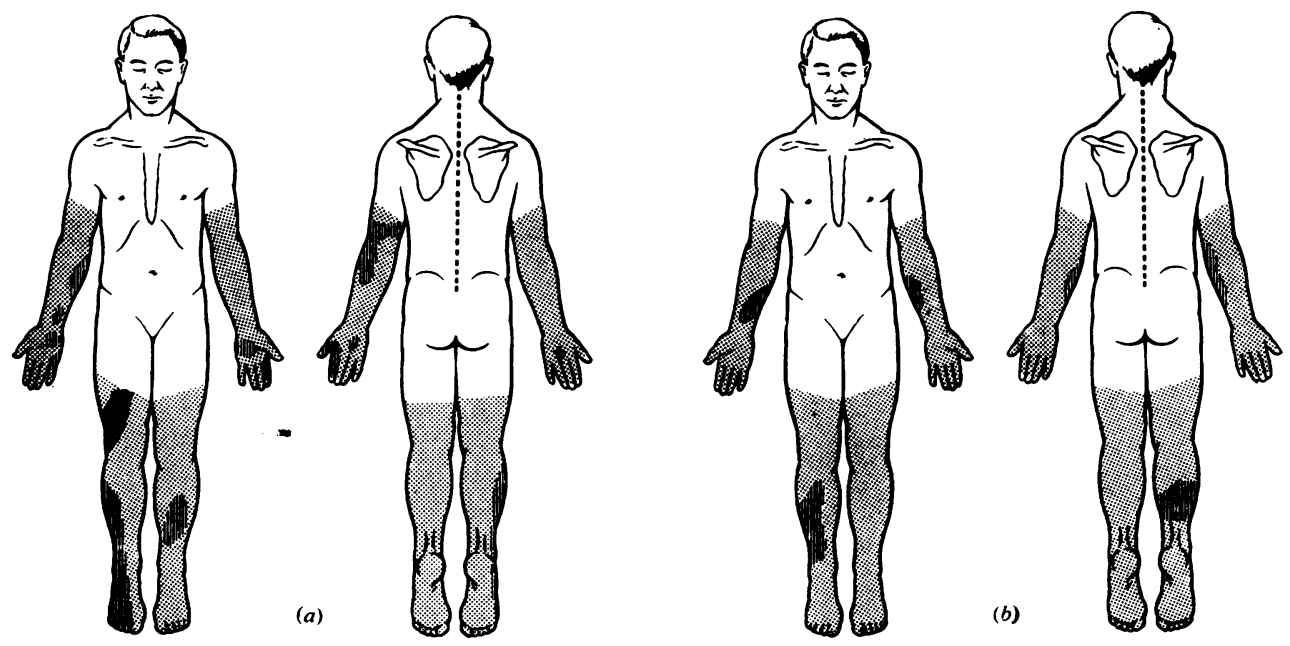

Fig. 4 ( $a$ and b). - Sweat loss in two patients with uncomplicated rheumatoid arthritis. See Fig. 2 for key. 


\section{Discussion}

Although Kuno (1956) has emphasized the individual variation in sweating patterns which can occur in different subjects, or in the same subject under different conditions, our small number of non-rheumatoid controls did not show much variation. Of the eighteen patients with rheumatoid arthritis and neuropathy, fifteen showed abnormalities of sweating beyond the minor irregularities seen in control subjects. Those with the most extensive sensory neuropathy tended to show the greatest sweating disturbances. The area of sensory loss usually corresponded with that of sweat loss, though this was not always the case, and in three patients with recovering neuropathy (Cases 4,5 , and 7) the areas of sweat loss were small. There are at least two possible reasons why sensory loss does not always correspond to areas of deficient sweating. Firstly, there may be overlapping sympathetic innervation to the sweat glands. Guttmann (1940), studying sweat responses after complete division of single peripheral nerves, found that the resulting area of total sweat loss was much smaller than the area of sensory disturbance, and was surrounded by an intermediate zone with diminished response. Secondly, some sympathetic nerve fibres do not run with the major peripheral nerves but accompany blood vessels to the periphery. These fibres would escape lesions involving main peripheral nerves and this would account for the small patches of sweating which were in fact always found on the finger tips and on some parts of the feet even in areas with complete analgesia. The converse may also be true, explaining the occasional disturbance of sweat response in the fingers and elsewhere in the absence of sensory disturbances.

In four patients (Cases 5, 8, 13, and 17) the pattern of sweat response was of preganglionic type, i.e. with deficient thermo-regulatory sweating but with acetyl choline and faradism responses present. But in all four the clinical neuropathy was recovering; and an alternative (and more likely) explanation to a preganglionic lesion is a postganglionic lesion with partial recovery, some response to acetyl choline and faradism returning before thermo-regulatory sweating can be demonstrated. We have not found any reports dealing with sweating responses during recovery and it appears that this should be investigated.

Postganglionic lesions were found in two subjects with severe sero-positive rheumatoid arthritis, neither of whom showed evidence of a sensory neuropathy though one had vascular lesions on the feet. A similar situation occurred in Case 18 where a pressure type of ulnar nerve lesion had recovered, but where extensive areas of sweat loss were present on the legs. The significance of autonomic lesions in these three patients is uncertain. They possibly represent the onset of neuropathy which will later involve the sensory nerves; alternatively autonomic neuropathy may be a separate clinical entity with selective involvement of the non-medullated autonomic nerve fibres. Further studies on this type of patient are required, because autonomic neuropathy could account for some of the vasomotor disturbances seen in rheumatoid arthritis, as suggested by Kalliomäki and others (1963). Whether these patients will develop sensory neuropathy or extension of the autonomic neuropathy can be determined only by follow-up studies. It is possible that sweat tests may come to be of value in assessing the prognosis in certain patients.

All patients who showed evidence of autonomic neuropathy were well-established cases of rheumatoid arthritis, in many cases with evidence of arteritis. All except Case 18 had a positive sheep cell agglutination test. A series of patients with sero-negative rheumatoid arthritis has not, however, been examined, so that no conclusions can be drawn about the association of autonomic neuropathy with positive sheep cell tests.

The relation between clinical rheumatoid neuropathy and sero-positivity is established (Pallis and Scott, 1965), and, except where mononeuritis is due to local pressure from a swollen or damaged joint, the various syndromes of rheumatoid somatic peripheral neuropathy appear to be associated with, and probably caused by, vascular lesions and ischaemia. Our finding now of autonomic neuropathy in most of these patients suggests that there is a frequent and topographic association between the two types of neuropathy and that the mechanism of both is similar.

\section{Summary}

The thermo-regulatory sweating response to immersion in warm water and the local sweating response to intradermal injection of acetyl choline and faradic stimulation have been tested in eighteen patients with rheumatoid arthritis and peripheral neuropathy, in eight patients with uncomplicated rheumatoid arthritis, and in thirteen non-rheumatoid control subjects, in order to differentiate lesions of pre- and postganglionic fibres.

In the control group, areas of deficient sweating were small and symmetrical.

In most of the patients with rheumatoid arthritis and peripheral neuropathy, there was sweat loss in areas corresponding approximately to those of 
cutaneous sensory impairment: this loss was usually of the type seen with interruption of postganglionic fibres, i.e. absent thermo-regulatory and local responses. In some patients the sweat response was normal. In four patients with thermo-regulatory sweat loss there was a positive local response suggestive of a preganglionic lesion, but in all four the clinical neuropathy was recovering or had recovered, and it is possible that the observed sweating abnormality represented a recovering postganglionic lesion rather than a preganglionic lesion.

Six of the eight patients with uncomplicated rheumatoid arthritis showed sweat responses similar to those of the control subjects, but two had larger areas of sweat loss: the significance of this is uncertain.

It is concluded that clinical sensory neuropathy in rheumatoid arthritis is usually accompanied by an autonomic neuropathy of postganglionic type corresponding to the sensory loss.

\section{REFERENCES}

Bárány,F.R., and Cooper, E.H.(1956). Clin.Sci., 15, 533. Bickford, R. G. (1938). Ibid., 3, 337.

Collins, K. J., and Weiner, J. S. (1961). Ibid., $21,333$.

Coon, J. M., and Rothman, S. (1940). J. Pharmacol. exp. Ther., 68, 301.

Guttmann, L. (1940). J. Neurol. Psychiat., N.S. 3, 197.

Hart, F. Dudley, Golding, J. R., and Mackenzie, D. H. (1957). Ann. rheum. Dis., 16, 471.

Hasama, B. (1930). Naunyn-Schmiedeberg's Arch. exp. Path. Pharmak., 153, 291.

Janowitz, H. D., and Grossman, M. I. (1950). J. invest. Derm., 14, 453.

Kalliomäki, J. L., Saarimaa, H. A., and Toivanen, P. (1963). Ann. rheum. Dis., 22, 46.

Kuno, Y. (1956). "Human Perspiration." Thomas, Springfield, Ill.

Lewis, T., and Marvin, H. M. (1927). J. Physiol. (Lond.), 64, 87.

List, C. F., and Peet, M. M. (1938). Arch. Neurol. Psychiat. (Chicago), 39, 1228.

Minor, V. (1927). Dtsch. Z. Nervenheilk., 101, 302.

Mitchell, G. A. G. (1953). "Anatomy of the Autonomic Nervous System." Livingstone, Edinburgh.

Pallis, C., and Scott, J. T. (1965). Brit. med.J., 1, in press.

Ropes, M. W., Bennett, G. A., Cobb, S., Jacox, R., and Jessar, R. A. (1959). Ann. rheum. Dis., 18, 49.

Rothman, S., and Coon, J. M. (1939). Arch. Derm. Syph. (Chicago), 40, 999.

Wilkins, R. W., Newman, H. W., and Doupe, J. (1938). Brain, 61, 290.

Neuropathie autonomique dans l'arthrite rhumatismale RÉSUMÉ

Pour différencier entre les lésions des fibres pré- et post-ganglionnaires on étudia la réponse sudoripare thermo-régulatrice à l'immersion dans l'eau chaude et la réponse sudoripare locale à l'injection intradermique d'acétylcholine et à la stimulation faradique chez 18 malades atteints d'arthrite rhumatismale et de neuropathie périphérique, chez 8 malades atteints d'arthrite rhumatismale incompliquée et chez 13 témoins non rhumatismaux.

Chez les témoins, les régions de sudation insuffisante étaient petites et symétriques.

Dans la plupart des cas d'arthrite rhumatismale et de neuropathie periphérique, la sudation était abolie dans les régions correspondant à peu près à celles des alterations sensorielles cutaníes; l'absence d'une réponse locale et thermo-régulatrice indiquait que la lésion était postganglionnaire. Chez chelques malades la réaction sudoripare était normale. Chez 4 malades la perte de la sudation thermo-régulatrice était accompagneé d'une réaction sudoripare locale positive, indiquant que la lésion était pré-ganglionnaire, mais chez tous les quatre, du point de vue clinique, la neuropathie était améliorée ou guárie; il est possible que l'anomalie sudoripare représente ici un lésion post-ganglionnaire en voie de guérison plutôt qu'une lésion pré-ganglionnaire.

Six malades sur huit, atteints d'arthrite rhumatismale incompliquée, ont accusé des réponses sudoripares similaires à celles des témoins, mais deux d'entre eux ont présentée de plus grandes surfaces de sudation; on ne sait pas exactement ce que cela signifie.

On conclut que la neuropathie sensorielle clinique dans l'arthrite rhumatismale est généralement accompagnée d'une neuropathie autonomique du type post-ganglionnaire à territoire commun.

\section{Neuropatía autonómica en la artritis reumatoide}

\section{SUMARIO}

Para diferenciar entre lesiones de fibras pre y postganglionares se estudió la respuesta sudorípara termoreguladora a la inmersión en el agua caliente y la respuesta sudorípara local a la inyección intradérmica de acetilcolina y a la estimulación farádica en 18 enfermos con artritis reumatoide y neuropatía periférica, en 8 enfermos con artritis reumatoide sin complicación y en 13 testigos sin reumatismo.

En los testigos, regiones de exudación deficiente fueron pequeñas y simétricas.

En la mayoría de los casos de artritis reumatoide y de neuropatía periférica la exudación fué perdida en regiones que correspondieron aproximadamente a las con alteraciones sensorias cutáneas; la reacción sudorípara local y termo-reguladora negativa indicó que la lesión fué post-ganglionar. En algunos enfermos la reacción sudorípara fué normal. En 4 enfermos la pérdida de la exudación termo-reguladora se vió acompañada de una reacción sudorípara local positiva sugeriendo una lesión pre-ganglionar, pero en todos ellos, clínicamente, se observó el restablecimiento parcial o completo de la neuropatía, de modo que se puede tratar aquí de mejorías de lesiones post-ganglionares.

De ocho enfermos con artritis reumatoide sin compliciones, seis acusaron reacciones sudoríparas similares a las de los testigos, pero dos otros presentaron mayores zonas de exudación; no es cierto el significado de esto.

Se concluye que la neuropatía sensoria clínica en la artritis reumatoide se acompaña generalmente de neuropatía autonómica del tipo post-ganglionar de distribución común. 